\title{
Aniela Dylus
}

\section{Koniunkcja demokracji i gospodarki? Perspektywa Centesimus annus}

\section{The Conjunction of Democracy and Economy? The perspective of Centesimus annus}

W artykule dokonana jest analiza relacji demokracji i gospodarki w perspektywie encykliki Jana Pawła II Centesimus annus. Powszechnie przyjmowana w latach '90 XX w. teza o zależności kapitalizmu od demokracji jest obecnie kwestionowana. Z jednej strony nowe fenomeny polityczne jakimi są rosnące w siłę ruchy populistyczne czy alterglobalistyczne $\mathrm{z}$ drugiej zaś nowe zjawiska gospodarcze jak working poor, pojawienie się prekariatu oraz finansjalizacja gospodarki zmuszają do postawienia pytania o przyszłość państwa demokratycznego. Jego dotychczasowa formuła wydaje się już na wyczerpaniu, natomiast wciąż nie jest klarowne, w którym kierunku mogłaby nastąpić jej metamorfoza.

Słowa kluczowe: demokracja, kapitalizm, Centesimus annus, kryzys gospodarczy

The article presents the analysis of the relationship between democracy and economy in the perspective of the encyclical letter of John Paul II Centesimus annus. The thesis of the dependence of capitalism upon democracy, commonly accepted in the 1990s, is now being called into question. On the one hand, new political phenomena such as growing populist or alter-globalist movements, on the other hand, new economic phenomena such as the working poor, the emergence of precariat and the financialization of the economy raise questions about the future of the democratic state. Its existing formula seems to come to an end, however, it is still not clear in which direction its metamorphosis could happen.

Key words: democracy, capitalism, Centesimus annus, economic crisis

\section{Wprowadzenie}

W debacie nad przyszłością demokracji nie można pomijać jej związku z gospodarką. Sięgając po ćwierćwieczu od ogłoszenia Centesimus annus (CA) do tekstu tego ważnego dokumentu warto zapytać, czy głos Jana Pawła II wnosi coś do tej debaty. Czy ustawione w 1991 r. drogowskazy także dziś wskazują właściwy kierunek? W niniejszym tekście 
zostanie podjęta próba identyfikacji najważniejszych zjawisk, procesów czy tendencji na styku demokratycznej polityki i gospodarki, które ujawniły się w ciągu ostatnich 25 lat, a następnie - spojrzenia na nie przez pryzmat nauczania zawartego w encyklice. Innymi słowy, chodzi tu o ustalenie, co napisałby Jan Paweł II w encyklice ogłoszonej z okazji 125-rocznicy Rerum novarum. Wobec dynamiki przemian, których jesteśmy świadkami, zwłaszcza rozdział II CA, zatytułowany „ «rzeczy nowe» naszych czasów”, w 2016 r. zapewne musiałby zostać napisany na nowo. Rzeczywistość gospodarcza wygląda przecież dziś inaczej niż w $1991 \mathrm{r}$.

W punkcie wyjścia tych rozważań jeszcze raz zostanie przywołana coraz częściej kwestionowana teza o współzależności demokracji i wolnego rynku (1). Następnie przyjrzymy się tym (wybranym) przemianom gospodarczym, które wpływają na kondycję demokratycznego państwa (2). Wreszcie zapytamy o możliwe scenariusze rozwoju sytuacji dotyczące relacji między demokratycznym państwem prawa a życiem gospodarczym (3).

\section{Problem współzależności demokracji i wolnego rynku}

W naukach o polityce, a jeszcze bardziej w potocznej świadomości nierozerwalny związek wolności politycznej i wolności gospodarczej wydawał się niekwestionowanym pewnikiem. Tym bardziej dotyczyło to państw naszego regionu, gdzie poniekąd na zasadzie zaprzeczenia doświadczaliśmy obowiązywalności tej tezy. Naocznie okazywało się, że tzw. dyktatura proletariatu jest wszechogarniająca. Nie znosi wyłomów. Opresyjny system monopartyjny idzie w parze z centralnym sterowaniem gospodarki, a śmiertelnym wrogiem obydwu są: niepokorne myślenie, wolne media i otwarte społeczeństwo. Po załamaniu się tego systemu w 1989 r. czymś oczywistym wydawał się wybór „demokratycznego kapitalizmu”. Wielkie było wówczas zapotrzebowanie na koncepcję zaprezentowaną przez Michaela Novaka. Duch demokratycznego kapitalizmu [Novak 2001] ${ }^{1}$ zawładnął umysłami wielu przedstawicieli elit naszego regionu.

Wprawdzie politologowie wypowiadali się ostrożniej, ale generalnie nie kwestionowali współzależności demokracji i wolnej gospodarki. Jeszcze w połowie XX w. Seymour M. Lipset pisał, że „demokracja pozostaje w związku z rozwojem ekonomicznym; im bardziej zamożny jest dany naród, tym większe jest prawdopodobieństwo tego, że panują w nim demokratyczne stosunki” [Sztumski 2008: 132]. Można przy tym zakładać, że ową zamożność Lipset kojarzył z wolnym, kapitalistycznym systemem gospodarczym. Nieco ostrożniej wypowiada się Samuel Huntington w klasycznej już pozycji z 1991 r. Trzecia fala

1 Wydany w 1982 r. The Spirit of Democratic Capitalism lub jego drugie wydanie z 1991 r. było w Polsce znane już wcześniej. 
demokratyzacji. W długiej liście zmiennych branych pod uwagę przy wyjaśnianiu demokracji i demokratyzacji na pierwszych miejscach znalazły się takie czynniki jak: „wysoki poziom ogólnego dobrobytu" $i$,gospodarka rynkowa”. Niemniej mając na uwadze demokratyzację takich krajów jak np. Indie, Kostaryka, Wenezuela, Turcja, Brazylia, Botswana, Grecja, Japonia, która miała miejsce w połowie XX w., czyli w czasie, kiedy niektóre z nich zmagały się z kwestią skrajnego ubóstwa, trzeba zrelatywizować znaczenie ww. czynników gospodarczych. W każdym razie wielość doświadczeń historycznych upoważnia do akceptacji twierdzenia Huntingtona: „żaden pojedynczy czynnik nie wystarcza, aby wyjaśnić rozwój demokracji we wszystkich krajach - lub tylko w jednym kraju”. Znaczy to, że „w każdym przypadku demokratyzacja jest rezultatem splotu różnych przyczyn” [Huntington 1993: 57n]. Próbując wyjaśnić trzecią falę demokratyzacji - z lat 70. i 80. oraz jej drugą fazę (po 1989 r.) autor ten słusznie zauważa: „Jakkolwiek czynniki ekonomiczne mają duże znaczenie, nie są one decydujące" [Huntington 1993: 66]. Stosunkowo wysoki poziom PKB w Czechosłowacji i NRD w połowie lat 70. nie miał wówczas wpływu na osłabienie politycznej dyktatury².

W podobnym kierunku idą analizy zawarte w CA. Papież z aprobatą konstatuje wyłonienie się po 1989 r. "nowych form demokracji” - i to mimo zrujnowanych gospodarek (CA 22). I Huntington, i Jan Paweł II zgodnie stwierdzają, że trudności gospodarcze są tylko jedną z wielu przyczyn upadku „systemów ucisku”. Huntington zwraca uwagę, że gospodarcza mizeria osłabia autorytarne reżimy, zaś dla autora CA „decydującym czynnikiem” implozji systemu było „pogwałcenie praw pracy” (CA 23). „Niesprawność systemu gospodarczego” uznaje wprawdzie jako „drugi czynnik kryzysu”, ale zaraz dodaje, że jest to raczej następstwo naruszenia praw człowieka: do inicjatywy, do własności, do wolności ekonomicznej. W końcu zaś „prawdziwą przyczyną” cudownych wydarzeń roku 1989 była „pustka duchowa wytworzona przez ateizm" (CA 24). Chodzi tu o zespół czynników doktrynalnych, trafnie zidentyfikowanych wcześniej lapidarnym stwierdzeniem: „podstawowy błąd socjalizmu ma charakter antropologiczny”. Podporządkowanie dobra jednostki mechanizmowi ekonomiczno-społecznemu, błędna koncepcja osoby, której źródłem jest ateizm (CA 13) musiały wywołać reakcję. Odkrywanie na nowo własnej tożsamości, sensu życia, religijnych korzeni kultury narodowej, a w końcu samej osoby Chrystusa (CA 24) tkwiło u podstaw wydarzeń roku 1989.

Wracając do problematycznej koincydencji demokracji i kapitalizmu - otóż mam wrażenie, że teza ta, ostrożnie formułowana przez politologów, pośrednio obecna także w CA - choć przy innym rozłożeniu akcentów, a powszechnie przyjmowana po upadku komunizmu,

2 To samo dotyczy takich krajów jak Arabia Saudyjska, Libia, Kuwejt, por. [Huntington 1993: 68-69]. 
chociażby w Polsce, po ćwierćwieczu coraz częściej bywa kontestowana. Dlaczego? W międzyczasie niedemokratyczne Chiny, gdzie permanentnie łamie się prawa człowieka, urosły do drugiej potęgi gospodarczej świata. Okazało się, że kraj bazujący na tzw. „wartościach azjatyckich”: wspólnotowości, harmonii, hierarchii społecznej, zaczerpniętych po części z ideologii komunistycznej, a po części z tradycji konfucjanizmu, w ciągu kilku dekad dokonał bezprzykładnego skoku cywilizacyjnego, bez porzucania opresyjnego systemu politycznego [Smolar 2011: 92-94]. W kilku innych państwach, chociażby w Azji Południowo-Wschodniej czy w Chile pod rządami Augusto Pinocheta, z powodzeniem łączy się dyktaturę (często - wojskową) z liberalnym systemem gospodarczym, co przynosi znaczące sukcesy gospodarcze. Uważa się, że nawet w Polsce żaden w pełni demokratyczny parlament nie wyraziłby zgody na tak radykalną liberalizację gospodarki, jaką zainicjował Leszek Balcerowicz pakietem dziesięciu ustaw, które weszły w życie 1 stycznia $1990 \mathrm{r}$.

W każdym razie teza o interdependencji demokracji i wolnego rynku jest dziś mniej oczywista niż 25 lat temu. Przyjmując ją jako pewnik zapomina się często, że obydwa zestawiane ze sobą człony mają niezwykle dynamiczny charakter. Podczas gdy wczesny wolnokonkurencyjny kapitalizm rzeczywiście sprzyjał rozwojowi demokracji liberalnej, to niekoniecznie dotyczy to kapitalizmu monopolistycznego ${ }^{3}$. Co więcej, zapewne $\mathrm{z}$ wielu względów „demokratyczny kapitalizm” utracił dziś siłę przyciągania, przestał być atrakcyjnym ideałem. Powodów tego stanu rzeczy można się doszukiwać i po stronie kapitalistycznej gospodarki, i po stronie demokracji. Zapytajmy więc, czy współczesny kapitalizm rzeczywiście sprzyja demokracji.

\section{Kondycja demokratycznego państwa w kontekście przemian gospodarczych}

Nie trzeba tu udowadniać tezy o marnej kondycji współczesnej demokracji. Doskwierają nam jej deficyty. Wprawdzie niektórzy wierzą, że dzięki intensyfikacji debaty publicznej $\mathrm{w}$ ramach różnych społeczności internetowych wzmocniona zostanie demokracja deliberatywna. Inni z kolei w nowych ruchach społecznych, zwłaszcza w tzw. ruchach protestu (np. alterglobalistycznych, „oburzonych” czy Anty-ACTA) widzą nowe formy ożywienia demokracji bezpośredniej. Doprowadzają one nie tylko do korekty błędnych decyzji różnych gremiów demokracji przedstawicielskiej, ale - jak na przykład w ramach „wiosny arabskiej" wręcz do wymiany elit rządzących.

Pomijając już fakt, że ruchy te raczej generują nowe zagrożenia demokratycznego porządku niż go naprawiają, generalnie dominuje dziś sceptycyzm i co do status quo, i co do

3 Zwraca na to uwagę m.in. Janusz Sztumski, por. [Sztumski 2008: 133n]. 
przyszłości demokracji. Niekiedy przybiera on nawet formę rezygnacji i zupełnego braku złudzeń co do demokratycznych zasobów współczesności oraz obywatelskiej gotowości do uczestnictwa w decyzjach politycznych [por. Frühbauer 2013]. Ten stan świadomości społecznej, ale i analiza kondycji demokratycznego ustroju znajduje wyraz w wielu publikacjach naukowych. Już ich tytuły sygnalizują kryzysową sytuację. Oto wybrane przykłady: Krucha demokracja [Rauscher 2007], Rozstrojona demokracja [Braun, Geisler 2012], Niemoralna demokracja [Stawrowski 2008], Demokracja peryferii [Krasnodębski 2003], Dylematy demokracji [Zwoliński 2010], Erozja demokracji? [Gabriel 2012], Postdemokracja [Crouch 2008], Koniec demokracji [Thielmann 2011: 820-823].

Spróbujmy tu zapytać o gospodarczy kontekst tego stanu rzeczy. Czy i w jakim sensie gospodarcze przemiany ostatniego ćwierćwiecza były jednym z czynników „odpływu demokracji”? Wydaje się, że wskazać tu trzeba przede wszystkim na dwa związane ze sobą zjawiska, tj. procesy globalizacji ${ }^{4} \mathrm{i}$ rozpoczęty w 2007 r. światowy kryzys gospodarczy oraz na wielorakie osłabiające demokrację konsekwencje tych fenomenów. Jak wiadomo, proces globalizacji, przyspieszony w dwóch ostatnich dekadach XX w. wielokrotnie był przedmiotem refleksji w nauczaniu społecznym Kościoła. Również w CA znajdujemy wzmiankę na temat procesu „powstawania współzależności gospodarczych na skalę światową”. I choć daleki od potępiania „rzeczy nowych” Jan Paweł II wyraźnie zaznacza: „zjawiska tego nie należy uważać za negatywne, gdyż może stwarzać niezwykłe możliwości osiągnięcia większego dobrobytu", to już w $1991 \mathrm{r}$. dostrzega też pewne zagrożenia z nim związane i wskazuje kierunki ich eliminacji ${ }^{5}$ (o czym szerzej - za chwilę). Niewątpliwie jednak zgubne dla demokracji skutki globalizacji w całej pełni ujawniły się na przełomie wieków i w pierwszych dekadach obecnego stulecia. Ponieważ wielokrotnie już je omawiano, zasygnalizuję jedynie występowanie niektórych $\mathrm{z}$ nich.

4 Na zagrożenia demokracji związane z globalizacją wskazuje wielu autorów. Oprócz już cytowanych por. także: [Brunkhorst, Kettner 2000], [Habisch, Hartmann, Schmidt, Wieland 2000]; [Polak 2008: 140-153], [Jaroszyńska 2008: 224-235].

5 W nauczaniu społecznym Jana Pawła II temat globalizacji pojawia się wielokrotnie w kolejnych po CA dokumentach: np. w adhortacji Ecclesia in America (ze stycznia 1999 r.), w Orędziach na Światowy Dzień Pokoju, Orędziach na Światowy Dzień Środków Społecznego Przekazu (Orędzie na XXXV Dzień z 24.01.2001 r. zostało zatytułowane: Rozgłaszajcie to na dachach: Ewangelia w epoce globalnej komunikacji). Niektóre z jego przemówień w całości lub w znacznej części są poświęcone temu zjawisku. Dotyczy to np. przemówień do uczestników sesji plenarnych Papieskiej Akademii Nauk Społecznych z 25.04.1997 r. (por. „Społeczeństwo” 1997 nr 4, s. 714-717) i z 27.04.2001 r. To ostatnie zostało nawet zatytułowane Globalizacja i etyka (por. Jan Paweł II 2011: 48-51). Warto tu zaznaczyć, że „globalizacja solidarności” jest postulatem właśnie tego papieża, podejmowanym i rozwijanym następnie przez Benedykta XVI i Franciszka. 


\section{Utrata prymatu polityki nad gospodarka}

W analizach procesu globalizacji powtarza się konstatacja, że napędzana rewolucją elektroniczną dynamika globalizacyjnych przemian w gospodarce znacznie wyprzedza przemiany polityczne. Tym bardziej, że towarzyszy im ideologia globalizmu, zgodnie z którą zderegulowane rynki najlepiej służą wzrostowi dobrobytu'. Na niebezpieczeństwo rozpowszechniania się takiej „radykalnej ideologii kapitalizmu” z jej „ślepą wiarą”, że wszelkie problemy społeczne, np. skrajnej nędzy materialnej, rozwiąże „swobodna gra sił rynkowych" wskazywał już Jan Paweł II (CA 42).

W konsekwencji globalizacji demokratyczne państwo przede wszystkim traci swą monopolistyczną pozycję na scenie światowej. W ostatnim ćwierćwieczu w strukturze globalnego rządzenia silną pozycję uzyskały korporacje ponadnarodowe. Charakterystyczne dla globalizacji: deterytorializacja zjawisk gospodarczych, ich dematerializacja, delokalizacja produkcji i usług dodatkowo osłabia pozycję państwa narodowego wobec ponadnarodowych podmiotów gospodarczych. To nie państwo dyktuje warunki firmom, ale odwrotnie. Konkurując o pozyskanie inwestorów zagranicznych, jest zmuszone do ustępstw podatkowych i deregulacji rynku, co oczywiście ogranicza możliwości prowadzenia polityki gospodarczej i społecznej na miarę oczekiwań obywateli. Nawet jeśli korporacje w ramach społecznej odpowiedzialności biznesu uzupełniają deficyty państwowej polityki społecznej, jeśli na przykład współfinansują ubezpieczenia społeczne, oferują dodatkowe programy emerytalne, świadczenia medyczne, edukacyjne i kulturalne, to jako prywatne podmioty, których władza pozbawiona jest demokratycznej legitymizacji, generują jedynie partykularne dobra prywatne, a nie dobra publiczne [por. Dylus 2016a: 336-341]. Wszystko to prowadzi do erozji demokratycznie legitymizowanej władzy państwa narodowego. Nierównowaga między koncernami działającymi w skali globalnej a parlamentami narodowymi ogranicza polityczną władzę decyzyjną i szkodzi przez to demokracji. Obywatele doświadczają jej bezsilności [Gabriel 2012: 7n].

Trzeba tu dodać, że relacje między polityką a gospodarką ulegają w historii dość znacznym wahaniom. Po II wojnie światowej, do lat 70. XX w., polityka - zdominowana ideałem welfare state - głęboko wchodziła w procesy gospodarcze i społeczne. Wraz z rewolucją konserwatywną i dominacją neoliberalnej doktryny gospodarczej - wycofywała się z tych

6 Autorem rozróżnienia między trudną do zatrzymania globalizacją a możliwym do zmodyfikowania przez odpowiednie decyzje polityczne globalizmem jest Ulrich Beck. Podaję za: [Gabriel 2012: 8].

7 Ten wątek podejmowali też jego następcy. Profetyczny sprzeciw wobec trickle down theory, tj. teorii swobodnego przepływu (dobrobytu) w dół, artykułował papież Franciszek w adhortacji Evangelii Gaudium (54). 
obszarów. Z kolei kryzys finansowy i gospodarczy 2008 + (o czym szerzej za chwilę) wymusił powrót państwa do gospodarki [Smolar 2011: 117].

Ponieważ zakres i sposób obecności państwa w gospodarce jest kluczowy dla „przyjaznego człowiekowi” systemu gospodarczego, obszerne fragmenty CA są poświęcone właśnie temu zagadnieniu. Jan Paweł II wiedział, że państwo nie może sobie pozwolić odbierać pełnienia niektórych funkcji. Nie wolno mu dyspensować się od gwarancji: indywidualnej wolności i własności, stabilności pieniądza i bezpieczeństwa, od czuwania nad realizacją praw ludzkich w życiu gospodarczym, od tworzenia warunków zapewniających możliwości pracy, a w sytuacjach wyjątkowych - od podejmowania innych jeszcze funkcji zastępczych. Doceniając zasługi w tym względzie „państwa dobrobytu”, Papież jednocześnie przestrzega przed przesadą, niesprawnością i nadużyciami tego modelu państwa. Zasłużył on na krytykę przede wszystkim ze względu na szeroki zakres interwencji bezpośrednich i „logikę biurokratyczną" powodującą ubezwłasnowolnienie obywateli i społeczeństwa (CA 48).

\section{Marginalizacja pracy}

W warunkach globalizacji dysproporcja między pracą i kapitałem - na niekorzyść pracy - ulega pogłębieniu [por. Dylus 2016b: 42-56]. Ze swej istoty praca jest bowiem - ze zrozumiałych względów - znacznie bardziej immobilna niż kapitał, zwłaszcza finansowy. W tej sytuacji niektórzy, np. Jeremy Rifkin, już w 1997 r. ogłosili „koniec pracy” [Rifkin 2001]. Podobnie jak proroctwo Francisa Fukuyamy o „końcu historii”, jest to zapewne zapowiedź przedwczesna (a raczej - wyraźnie fałszywa). Można ją jednak interpretować jako sygnalizację marginalizacji tego czynnika gospodarczego. Jej przejawem jest nie tylko bezrobocie, ale też niepełne zatrudnienie i w ogóle trudność zakorzenienia się na rynku pracy, zwłaszcza młodzieży. Pojawia się zjawisko „biednych pracujących” (working poor). Rozwój gospodarki opartej na wiedzy oznacza spadek popytu na pracowników niewykwalifikowanych lub wykwalifikowanych wąsko specjalistycznie. Poza tym nowe techniki i technologie znacznie zmniejszają zapotrzebowanie na proste prace produkcyjne. W miarę postępującej komputeryzacji popyt na rutynową pracę odtwórczą: i fizyczną, i umysłową dalej będzie spadać.

W ogóle na globalnym rynku pracy obserwuje się ciągły ruch i przetasowania, pozostawiające za sobą sporo ofiar. Stabilne w epoce przemysłowej stosunki pracy, regulowane trwałymi umowami o pracę, nad których realizacją czuwali partnerzy społeczni, bezpowrotnie należą do przeszłości. Gwałtownie następuje serwicyzacja gospodarki. W najbogatszych państwach udział usług w tworzeniu PKB sięga nawet 80 proc. $^{8}$. Dominacja

8 Z kolei reakcją na serwicyzację gospodarki są próby jej reindustrializacji. Dotyczy to i Unii Europejskiej, i Polski. 
usług dodatkowo wymusza większą elastyczność: i czasu pracy, i charakteru samej umowy o pracę, i miejsca pracy. W epoce postfordyzmu przebieg pracy zawodowej radykalnie się zmienia. Jak sygnalizują eksperci, obecnie charakterystyczne jest mianowicie „przeplatanie się okresów, w których jest się pracownikiem, bezrobotnym, samozatrudnionym, osobą zatrudnioną niepracowniczo czy na cząstkowy wymiar pracy. Następuje także łączenie tych form aktywności” [Surdykowska 2007: 20].

Właściwa dla opartej na wiedzy „nowej gospodarki” rosnąca niepewność gospodarowania zagraża stabilności przedsiębiorstw. Część tej niepewności przerzuca się zatem na pracowników. Zatrudnienie na mobilnych zasadach („umowy śmieciowe”), bez gwarancji bezpieczeństwa socjalnego, nie daje oczywiście stabilizacji. Narzucone pracownikom nietypowe i elastyczne formy zatrudnienia, w tym tzw. telepraca, wiążą się często z przemęczeniem, nierytmicznością i nieprzewidywalnością czasu pracy oraz wykonywaniem jej w tzw. porach aspołecznych. Trudno wtedy zsynchronizować obowiązki domowe i zawodowe oraz czas wolny poszczególnych członków rodziny, co ogranicza relacje między nimi.

Mając na uwadze wszystkie te zjawiska, godzi się tu przypomnieć stwierdzenia Jana Pawła II, że jedną z funkcji państwa jest „czuwanie nad realizowaniem praw ludzkich w dziedzinie gospodarczej" (CA 48).

\section{Prekariat}

W ocenie niektórych ekspertów kompleks zagadnień związanych z marginalizacją pracy urasta nawet do „nowej kwestii społecznej” [por. Rymsza 2015: 15], na którą składa się m.in. bolesne zjawisko prekariatu. Kojarzone są z nim najczęściej: brak bezpieczeństwa, niepewność, lęk, obawa o przyszłość. Konsekwencje tej sytuacji daleko wykraczają poza stosunki pracy. Według Guy Standinga psychologicznymi i społecznymi skutkami charakterystycznego dla prekariatu zachwiania bezpieczeństwa są: gniew, anomia, objawiająca się biernością wynikającą z niepowodzeń, niepokój, którego źródłem jest lęk o przyszłość i alienacja zrodzona z braku szacunku do własnej pracy. Wszystko to grozi utratą poczucia tożsamości związanej z pracą oraz wypchnięciem jednostki poza instytucje ładu rynkowego i porządku społecznego [Standing 2014: 65-73].

Jeszcze inną twarzą prekariatu jest społeczna izolacja jednostek w procesie pracy. Grozi ona i pracującym w domu telepracownikom, i bardzo poszukiwanym w ponadnarodowych korporacjach pracownikom „dyspozycyjnym”, nie związanym na stałe ani z wyuczonym zawodem, ani z rodziną, ani z miejscem zamieszkania. Ci mobilni kosmopolici zainteresowani są przede wszystkim „samorealizacją”. Na fundamencie „obowiązków względem 
samego siebie" rozwija się nowa etyka, zawierająca m.in. wątki narcystyczne. Bierze ona w nawias społeczny charakter obowiązków, koncentruje się za to na egoistycznym odcinaniu się od bliźnich [por. Kreikebaum 1999: 55n].

Brak trwałego zakorzenienia we wspólnocie: zakładu pracy, ale też zawodu, rodziny, ojczyzny (małej i dużej) - w związku z nowymi trendami w odniesieniu do pracy wymuszającymi wszelaką dyspozycyjność i mobilność - skutkuje naruszeniem poczucia własnej godności. Dotykamy w ten sposób najgłębszej warstwy prekariatu, trafnie wyartykułowanej w pewnym artykule: „Prekariuszem jest więc nie tylko człowiek niezabezpieczony finansowo, ale także ten, komu nikt - ani instytucje państwa, ani osoby, z którymi pracuje, ani nawet najbliżsi, których jest coraz mniej w zatomizowanym społeczeństwie - nie przekazuje jednego, podstawowego przesłania: «Ty jesteś prawdziwą wartością». Prekariuszem jest człowiek samotny wśród bliskich” [Piekutowski 2015: 27].

Nie trzeba już chyba dodawać, że wszystkie te przemiany w świecie pracy: bezrobocie, niepełne zatrudnienie, brak zakorzenienia w instytucjach ładu rynkowego, elastyczność i mobilność pracy, zjawisko working poor oraz skrajne zindywidualizowanie pracowników może wywoływać wielorakie perturbacje osobiste i społeczne. Przede wszystkim spada poczucie bezpieczeństwa socjalnego i społecznego. W ten sposób tworzą się idealne warunki dla mobilizacji „potencjału antydemokratycznego”. Tym bardziej, że zasłużone w obronie słusznych uprawnień pracowniczych związki zawodowe i w ogóle demokracja gospodarcza również przeżywają głęboki kryzys. W tej sytuacji dyskurs wokół „nowej demokracji gospodarczej” poniekąd uzupełnia namysł nad przyszłością demokracji [Frühbauer 2013: 3].

\section{Kryzys związków zawodowych i demokracji gospodarczej}

Wraz z przemianami postindustrialnymi znaczenie związków zawodowych, uznawanych jeszcze w Laborem exercens (LE) jako „nieodzowny składnik życia społecznego” (LE 20) wyraźnie słabnie. Według zgodnej diagnozy wielu autorów, „przeżywają (one) głęboki kryzys wyrażający się głównie spadkiem stopy uzwiązkowienia”. Ich naturalnym środowiskiem są fabryki - wielkie zakłady przemysłowe. Trudniej odnajdują się natomiast w mobilnym sektorze małych i średnich przedsiębiorstw, działających na mocno konkurencyjnych rynkach oraz zatrudniających pracowników na nietypowych zasadach i w elastycznym czasie pracy. Oznacza to, że związków zawodowych nie ma „tam, gdzie są najpotrzebniejsze” [Bednarski 2015: 144]. W CA przypomniano ich znaczenie jako organizacji, które „bronią praw ludzi pracy i ochraniają ich podmiotowość, spełniając jednocześnie istotną funkcję kulturową" (CA 35). 
Wydaje się, że dziś największym wyzwaniem dla związków zawodowych jest pozyskiwanie nowych członków właśnie wśród zatrudnionych w elastycznych formach, szczególnie w sektorze usług. Ponieważ często pracownikami są tu osoby o niskich kwalifikacjach, łatwo zastępowalne innymi, boją się one przystępowania do związku zawodowego [Surdykowska 2007: 24].

W kontekście globalizacyjnych przemian nie ma też wielkiego zapotrzebowania na pracowniczą partycypację (niem. Mitbestimmung) w zarządzaniu, we własności i zyskach. $\mathrm{Z}$ drugiej strony warunkiem skutecznego przeniesienia demokratycznych idei i reguł do obszaru gospodarki jest dobrze funkcjonująca demokracja polityczna. Tymczasem w epoce globalizacji, kiedy demokratyczne instytucje poszczególnych państw w znacznym stopniu są sparaliżowane, warunek ten nie jest spełniony. Dlatego w kontekście dominacji doktryn neoliberalnych i zderegulowanego kapitalizmu finansowego, odpowiedzialnego za światowy kryzys, pojawia się postulat wypracowania koncepcji „nowej demokracji gospodarczej”. Wobec tendencji postdemokratycznych, braku zainteresowania polityczną partycypacją, słabości związków zawodowych trudno jednak oczekiwać, że projekt ten przyczyni się do sanacji demokracji. Tym bardziej, że listę jego celów otwiera kontrowersyjna i skompromitowana idea „demokratyzacji wszystkich obszarów życia”, kojarzona z lewicową programatyką [Frühbauer 2013: 8-13].

Finansjalizacja gospodarki i światowy kryzys $2008+$

W zdematerializowanej (w znacznym stopniu) gospodarce światowej ogromnie wzrosło znaczenie kapitału finansowego. Nastąpił dynamiczny, niekontrolowany rozwój transakcji finansowych. Te zaś w dużej mierze mają charakter spekulacyjny. Słusznie zatem system oparty na takim hazardzie określa się „kapitalizmem kasyna”. Niekiedy w ogóle odmawia się mu miana „kapitalizmu”. Każda wolność, także wolność rynkowa potrzebuje reguł - przypomniał w jednym ze swoich ostatnich wywiadów Ralf Dahrendorf [Dahrendorf 2008]. Podobne treści znajdujemy w CA. Zastanawiając się przed 25 laty, czy po klęsce komunizmu kapitalizm może być alternatywą dla państw poszukujących właściwej drogi rozwoju, Jan Paweł II wiedział, że odpowiedź zależy od sposobu rozumienia „kapitalizmu”. W każdym razie pożądaną alternatywą na pewno nie jest „system, w którym wolność gospodarcza nie jest ujęta w ramy systemu prawnego, wprzęgającego ją w służbę integralnej wolności ludzkiej” (CA 42). Papież wyraźnie zaznaczał, że działalność gospodarcza „nie może przebiegać w próżni instytucjonalnej, prawnej i politycznej” (CA 48).

Tymczasem wbrew tym zdecydowanym przestrogom, w ostatnim czasie kapitalizm finansowy usamodzielnił się. Takie operacje, jak np. spekulacje na długach, są przykładem 
działań niczym nie uregulowanych. Zdaniem Dahrendorfa taki pozbawiony reguł obszar trudno w ogóle nazwać rynkiem [Dahrendorf 2008]. Ekspansja zderegulowanych „rynków” finansowych powoduje zaś, że gospodarka staje się bardzo podatna na nieoczekiwane wstrząsy. Wielki kryzys finansowy i gospodarczy, który w 2008 r. wybuchł w USA i szybko ogarnął cały świat, pokazał kruchość „sfinansjalizowanej” gospodarki. Formą ucieczki przed generowanymi przez kryzys konfliktami społecznymi jest zapożyczanie się u przyszłych pokoleń. Oznacza to ogromne zadłużenie wielu państw, wręcz zagrażające ich suwerenności.

Kryzys finansowy i gospodarczy pierwszej dekady XXI w. prowokował pytania, czy nie zagraża on demokracji ${ }^{9}$. Doszukując się analogii z wielkim kryzysem lat 30 . XX w. zastanawiano się, czy nie wywoła on równie zgubnych skutków: umocnienia radykalnego nacjonalizmu, ruchów totalitarnych, wręcz zbrojnego konfliktu. Dziś już wiadomo, że - owszem - spadła popularność rządzących, wiara w niektóre instytucje demokratyczne i w ogóle zaufanie do polityków i polityki, przejawiające się np. odmową udziału w wyborach, ale generalnie demokracja jako zasada organizacji polityki, przynajmniej na razie, nie została zakwestionowana. Poza tym wzrosła popularność różnych ruchów: populistycznych czy protestu, ale nie miały one ambicji obalania demokratycznych rządów. Nie znaczy to, że demokracja wyszła z tej sytuacji zupełnie bez szwanku. Kryzys gospodarczy po raz kolejny bezlitośnie odsłonił wady tego „najgorszego ustroju”: niemożliwość strategicznego projektowania reform zakrojonych długofalowo (w związku z presją cykli wyborczych) czy unikanie szybkich i odważnych, choć bolesnych decyzji. Zapewne demokratycznym politykom brakuje też cnoty męstwa „we wprowadzaniu w życie decyzji trudnych i bolesnych, lecz koniecznych” (CA 32), którą Jan Paweł II uznawał za niezbędną przy reformowaniu przedsiębiorstw. Wszystko to powoduje, że w obliczu kryzysu rośnie polaryzacja polityczna, a poparcie elektoratu uzyskują partie skrajne[Smolar 2011: 92, 100].

Kolejną wadą demokracji jest bowiem możliwość osiągania zwycięstwa wyborczego przez ugrupowania jej wrogie. Dotyczy to nie tylko państw naszego regionu. Choć poziom aprobaty idei demokracji jest tu wysoki - porównywalny ze społeczeństwami Europy Zachodniej, to w naszej części kontynentu znacznie wyższa jest aprobata tezy, że w pewnych warunkach rządy niedemokratyczne są lepsze. Zapewne nie tylko kryzys gospodarczy przyczynił się w Europie do „zwrotu w prawo” - do wzrostu zagrożenia nacjonalistycznego i ożywienia XIX-wiecznego sposobu rozumienia suwerenności. Jeśli dodać do tego bardzo

9 Choć trudno nie zgodzić się z tezą, że demokrację erodują głównie czynniki endogenne, w tym degradacja mechanizmów odpowiedzialności rządzących, to jednak gwałtowny spadek wzrostu gospodarczego też może jej zagrażać, por. [Nowotarski 2011: 104]. 
niski poziom zaufania do instytucji politycznych, zwłaszcza do partii, deficyty kultury politycznej, niestabilność sceny politycznej, to kondycja i przyszłość demokracji w Europie musi budzić troskę [Antoszewski 2011: 102n].

\section{Rozwierające się nożyce nierówności}

Spośród różnych konsekwencji globalizacji i kryzysu gospodarczego bodaj najgroźniejszy dla demokracji jest wzrost nierówności społecznych. Na sporządzonej przez Samuela Huntingtona liście 25 zmiennych branych pod uwagę przy wyjaśnianiu procesu demokracji i demokratyzacji „relatywnie równy podział dochodu i/lub bogactwa narodowego" znalazł się na drugim miejscu (po „wysokim poziomie ogólnego dobrobytu”, a przed „gospodarką rynkową)" [Huntington 1993: 57]. Powodowane globalizacją rozwieranie się nożyc nierówności szkodzi demokracji, gdyż powoduje zachwianie bezpieczeństwa socjalnego. Dochodzi do zetknięcia się antyegalitarnego wolnego rynku z egalitarną demokracją. Po przekroczeniu pewnego progu nierówności ekonomicznych i socjalnych (jego wysokość będzie inna w różnych społecznościach i kulturach), demokracja może zostać zawieszona. Podstawowe demokratyczne wolności stają się wówczas bezbronne wobec ruchów populistycznych, odwołujących się do frustracji, fobii, agresji. Zbyt ostentacyjna konsumpcja z jednej strony i pauperyzacja z drugiej, mogą prowadzić do groźnego konfliktu. Stanowią pożywkę dla demagogicznych stronnictw politycznych i ich ludowych trybunów. W ten sposób bezpośrednio zagrażają demokratycznemu porządkowi społecznemu [Dylus 2016a: 343n]. Z drugiej zaś strony również konsumizm nie sprzyja demokracji. Jak czytamy w CA, zdominowanie życia kategoriami „mieć i używać” powoduje, że człowiek nie może być wolny" (CA 42).

Tymczasem w ciągu ostatnich kilku dekad nierówności dochodowe i majątkowe ogromnie wzrosły - $\mathrm{i}$ to nie tylko w USA. W Europie wzrost dysproporcji związany był z demontażem państwa dobrobytu, z ograniczonymi finansowymi możliwościami prowadzenia przez państwo redystrybucyjnej polityki społecznej i z redukcją dostarczanych obywatelom dóbr publicznych, co wywołało (chociażby w Grecji) falę sprzeciwu i kontestacji wobec liberalnej demokracji. Przy zdecydowanie krytycznym podejściu Jana Pawła II do welfare state, był on jednak przekonany, że wobec „nowego kapitalizmu”, właśnie na państwie (i całym społeczeństwie) „spoczywa obowiązek obrony dóbr zbiorowych” (CA 40). Niedopełnienie tego obowiązku powoduje utratę przez obywateli wiary, że demokratyczne rządy są w stanie uporać się z trudnościami.

Trzeba jednak przyznać, że znalezienie równowagi między liberalizmem politycznym i gospodarczym, między wolnością a społeczną równością zawsze było skrajnie trudne. Dla 
Ralfa Dahrendorfa była to wręcz „kwadratura koła”. Warto przypomnieć, że model społecznej gospodarki rynkowej oparty był właśnie na próbie pogodzenia tej „wody z ogniem” (by przywołać jeszcze jedną metaforę dotyczącą aksjologii tego modelu). Niewątpliwie sukces „kapitalizmu nadreńskiego" był ogromnym wkładem do stabilizacji demokracji po II wojnie światowej ${ }^{10}$. Nic dziwnego, że system ten realizowany „w niektórych krajach” spotkał się z aprobatą Jana Pawła II (por. CA 19) ${ }^{11}$.

Mając na uwadze omówione wyżej te wybrane przemiany gospodarcze, które naruszają kondycję demokracji, warto na końcu zapytać o możliwe scenariusze rozwoju sytuacji.

\section{Możliwe scenariusze rozwoju sytuacji}

Spośród tych scenariuszy rozważyć należy dwie ewentualności. Warto mianowicie ustalić, czy pojawiają się jakieś przesłanki „globalizacji demokracji” czy też - przeciwnie - obserwuje się raczej tendencję „powrotu państwa”, związaną niekiedy z kolejną falą „odpływu demokracji"?

\section{„Globalizacja demokracji” (global governance)}

Już w 1997 r. ekonomista Dany Rodrik sformułował szeroko dziś dyskutowany trylemat. Uważał, że spośród trzech wartości: narodowej suwerenności, demokracji politycznej i pełnej integracji z globalnym wolnym rynkiem tylko dwie mogą być udziałem nowoczesnych państw [por. Hausner 2011: 112; Kuź 2015: 1]. Wobec takich i podobnych trudności towarzyszących globalizacji zastanawiano się, czy rozwiązaniem nie jest jakaś forma „globalizacji demokracji”. Wymownie ujął to Benjamin Barber: „Kapitalizm nie da się zdeglobalizować. Musimy natomiast zglobalizować społeczeństwo obywatelskie i demokrację. Muszą one dopędzić kapitalizm, dopaść go tam, gdzie dotarł, poza granicami państwa narodowego i odtworzyć w skali międzynarodowej zespół instytucji na podobieństwo tych, które wyrastały w sposób naturalny w ramach tradycyjnych państw narodowych” [Barber 2000].

Nie jest to głos odosobniony. W obliczu „zglobalizowanego kapitalizmu” od dawna sygnalizuje się potrzebę istnienia jakiegoś światowego porządku prawnego, zdolnego chociażby do stworzenia sprawnego „systemu konkurencji”, obowiązującego w skali ponadnarodowej. Świat stał się kompleksowy, wielopoziomowy, a władza - rozproszona. Potrzebne jest więc - dowodzi Jerzy Hausner - „dostosowanie władzy do tego, co jest, czyli wykreowanie mechanizmu wielopoziomowego zarządzania, a także aktorów, którzy

${ }^{10}$ Przypomniała to Ingeborg Gabriel, por. [Gabriel 2012: 9].

${ }^{11}$ Wprawdzie nie ma tu mowy expressis verbis o społecznej gospodarce rynkowej, ale charakterystyka akceptowanego ustroju gospodarczego pozwala na taki właśnie wniosek. 
są zdolni uczestniczyć w wielopoziomowym zarządzaniu” [Hausner 2011: 113]. Innymi słowy, globalizacja gospodarcza ma iść w parze z jakąś formą "globalizacji politycznej”.

Podobny wątek wyraźnie jest też obecny w CA. Umiędzynarodowieniu gospodarki ma mianowicie towarzyszyć powstawanie „organów kontrolnych i kierowniczych” skutecznie działających w skali międzynarodowej, „dzięki którym gospodarka służyłaby dobru wspólnemu”. Dla realizacji tego celu Papież zachęca wielkie kraje do „harmonijnej współpracy” oraz do „równoprawnej reprezentacji w instytucjach międzynarodowych interesów całej wielkiej rodziny ludzkiej” (CA 58). Choć są to dość ogólne postulaty, możemy się w nich doszukać zarysu koncepcji „zarządzania globalnego” (global governance).

Autorami przemyśleń na temat „globalizacji demokracji” są chociażby uczeni tej miary, co filozof Otfried Höffe czy politolog David Held. Obydwaj piszą o „uniwersalnym państwie minimalnym”, budowanym na istniejących już instytucjach międzynarodowych. Chodzi im o budowę światowego porządku prawnego opartego na fundamencie sprawiedliwości i o demokratyczną organizację, której konstytucyjną podstawą byłyby prawa człowieka, podział władz oraz zasady sprawiedliwości i federalizmu. Światowy parlament miałby się zajmować sprawami, które da się uporządkować tylko w skali globalnej, takimi jak np. zabezpieczenie pokoju, zachowanie zdrowego środowiska naturalnego, ograniczenie międzynarodowego terroryzmu, handlu narkotykami, redukcja broni ABC i inne. Oczywiście, taka „kosmopolityczna demokracja”, będąca bardziej skonsolidowaną i skuteczniejszą wersją ONZ, potrzebuje regionalnych płaszczyzn pośrednich, a także ponadnarodowych organizacji pozarządowych, będących zalążkiem światowej opinii publicznej [Höffe 2004].

Póki co trudno sobie wyobrazić sposób demokratycznej legitymizacji takich struktur, zaś ich realizacja, nawet w długiej perspektywie czasowej wydaje się iluzoryczna. Rzeczywiście, demokracja jest wytworem państwa narodowego, a zatem pomysły tworzenia „republiki światowej” wydają się utopijne. Prawdą jest jednak, że w obliczu omówionych wyżej przemian, czysto narodowa forma demokracji, która sprawdzała się jeszcze kilka dekad temu, dziś okazuje się niewystarczająca i chwiejna [Gabriel 2012: 13]. Nie znaczy to, że należy ją spisywać na straty. Ogłaszanie przez niektórych końca państwa narodowego było zdecydowanie przedwczesne.

\section{„Powrót państwa” (demokratycznego?)}

Wydaje się, że w wielu państwach wysoką koniunkturę notuje dziś opcja wzmacniania jednej spośród trzech zestawianych ze sobą przez Dany Rodrika wartości: narodowej 
suwerenności, kosztem gospodarczej globalizacji (losy demokracji pozostają - jak się wydaje - pewną niewiadomą). Prawdopodobnie właśnie tego domaga się dziś „lud”, o czym świadczą wyniki wyborów w latach 2015-2016 w niektórych państwach europejskich i w USA. Zapleczem ideowym tej opcji jest konserwatywny nurt myśli politycznej, tradycyjnie podkreślający znaczenie państwa (a także rodziny i własności prywatnej) jako filaru zdrowego porządku społecznego. Mimo kryzysu, przyszłość należy właśnie do państwa narodowego.

W nauczaniu społecznym Kościoła od Rerum novarum - co przypomniano w CA - znajdujemy wsparcie dla idei „państwa prawa” obecnego także w życiu gospodarczym. Owszem, „istnieje sfera uzasadnionej autonomii gospodarki” - pisze Jan Paweł II; zaraz jednak dodaje, że państwo ma „obowiązek określania ram prawnych” gospodarki i tworzenia „podstawowych warunków wolnej ekonomii”. W ten sposób pośrednio, zgodnie z zasadą pomocniczości, wspiera tworzenie miejsc pracy i dobrobyt społeczny. Oprócz tego ma też działać bezpośrednio, zgodnie z zasadą solidarności, np. ustalając w obronie słabszego minimalne warunki pracy i płacy, nawet jeśli będzie to oznaczało pewne ograniczenie autonomii podmiotów gospodarujących (CA 15).

Stanowisko podkreślające niezastąpioną rolę państwa narodowego dobrze artykułuje tytuł pewnej publikacji: Wielość państw w jednym świecie - apologia [Isensee 2003: 7-31] ${ }^{12}$. Jednocześnie projekty kosmopolitycznej demokracji, federalnej republiki światowej czy państwa uniwersalnego deprecjonowane są jako utopijne ogólniki ${ }^{13}$. Hasła w rodzaju „powrót państwa”, „widzialna ręka państwa” czy „reregulacja rynków finansowych” zyskały na popularności zwłaszcza w kontekście kryzysu finansowego i gospodarczego $2008+$ [por. Frühbauer 2013: 4]. Może się to wiązać z pewnym zamykaniem gospodarek, ochroną własnych rynków, wzrostem ceł, ale też ze wzmocnieniem tendencji autorytarnych. Trudno powiedzieć, czy silne państwo, którego powrotu domagają się dziś obywatele, będzie jeszcze państwem demokracji liberalnej.

John Saul w książce The Collapse of Globalism nie wyklucza scenariusza załamania się takiego państwa. Dopatrując się analogii z sytuacją na początku XX w., przewiduje krach globalizacji, powrót do protekcjonizmu, pojawienie się neonacjonalizmu, a może nawet

${ }^{12}$ Warto dodać, że autor jest znanym konstytucjonalistą niemieckim.

${ }_{13}$ Tymczasem podobne projekty spotykamy też w nauczaniu społecznym Kościoła. Krytyczny wobec postulatu Benedykta XVI „politycznej władzy światowej” dla „zarządzania światową ekonomią” i „zapobieżenia pogłębianiu się kryzysu” (Caritas in veritate 67) jest Maciej Zięba. Zarzuca mu maksymalizm i brak realizmu, por. [Zięba 2016: 106-107]. 
okres dominacji przemocy (czego zapowiedzią był 11 września 2001 r.). W odniesieniu do przemian w Europie Środkowej i Wschodniej z sympatią konstatuje, że „państwo narodowe wróciło do serca Europy" [Saul 2006].

Trudno jednak w tym miejscu uchylić się od postawienia pytania, czy wraz z „powrotem państwa” nie nastąpi kolejny „odpływ demokracji”. Tym bardziej, że dotychczasowe meandry kolejnych przypływów i odpływów demokracji skłoniły Samuela Huntingtona do sformułowania tezy, że jej przebieg następuje według reguły „dwa kroki do przodu, jeden do tyłu". W związku z tym w $1991 \mathrm{r}$. pisał o niezbyt optymistycznych prognozach dla demokracji [Huntington 1993: 50]. Z kolei 20 lat później badania dotyczące stanu demokracji w świecie, a ogłoszone przez „The Economist” potwierdzily te przewidywania [por. Antoszewski 2011:102]. Okazało się, że nawet w Europie, w krajach uznawanych za zaawansowane demokracje, stan tego ustroju uległ pogorszeniu (za wyjątkiem Europy Północnej). W badaniach uwzględniono przy tym m.in. poziom zaufania do instytucji, aprobaty dla idei demokracji, obniżanie się frekwencji wyborczej. Światłem ostrzegawczym dla demokracji są też sukcesy radykalnej prawicy w wielu państwach europejskich. Zapewne jednym z czynników spadku zaufania do demokracji był kryzys finansowy i gospodarczy oraz jego uciążliwe konsekwencje. Spadek poczucia bezpieczeństwa socjalnego, napływ do Europy fali uchodźców, zagrożenie terrorystyczne, niebezpieczeństwo islamizacji Starego Kontynentu to kolejne czynniki, które mogą przyczynić się do realizacji prognozy Samuela Huntingtona.

Wszystkich omówionych wyżej przemian gospodarczych i innych czynników determinujących kondycję demokracji, a składających się na „«rzeczy nowe» naszych czasów” a.D. 2016 nie mógł oczywiście znać Jan Paweł II. Jednak przywołane wybiórczo niektóre jego wskazania co do prawidłowych relacji między demokratycznym państwem a życiem gospodarczym nie straciły na aktualności. Kierowanie się nimi pozwoliłoby uniknąć wielu sygnalizowanych tu trudności i kryzysów.

Aniela Dylus - politolog i etyk, profesor nauk humanistycznych, dyrektor Instytutu Politologii Uniwersytetu Kardynała Stefana Wyszyńskiego w Warszawie w latach 2008-2012, członkini wielu stowarzyszeń naukowych (m.in.: „Societas Ethica”, Görres-Gesellschaft, Polskiego Towarzystwa Nauk Politycznych). Opublikowała m.in.: Moralność krańcowa jako problem dla katolickiej nauki społecznej (1992), Zmienność i ciagłość. Polskie transformacje ustrojowe w horyzoncie etycznym (1997), Globalny rynek i jego granice (2001), Globalizacja. Refleksje etyczne (2005), Polityka w perspektywie etycznej i religijnej (2016), Gospodarka $w$ perspektywie etycznej i religijnej (2016). 


\section{Bibliografia:}

Antoszewski A. (2011), Demokracja i kryzys, „Zarządzanie Publiczne” nr 2-3.

Barber B. R. (2000), Globalny dżin, „Gazeta Wyborcza”, 1-2 lipca.

Bednarski M. (2015), Czas pracy w polskiej gospodarce. Ewolucja, jej przyczyny i konsekwencje zmian, w: Ł. Hardt, D. Milczarek-Andrzejewska (red.), Ekonomia jest piękna? Księga dedykowana Profesorowi Jerzemu Wilkinowi, Wyd. Naukowe Scholar, Warszawa.

Braun S., Geisler A. (Hrsg.) (2012), Die verstimmte Demokratie. Moderne Volksherrschaft zwischen Aufbruch und Frustration, VS Verlag für Sozialwissenschaften, Wiesbaden.

Brunkhorst H., Kettner M. (Hrsg.) (2000), Globalisierung und Demokratie. Wirtschaft, Recht, Medien, surkamp taschenbuch, Frankfurt a.M.

Crouch C. (2008), Postdemokratie, edition surkamp, Frankfurt a.M.

Dahrendorf R. (2008), Keiner fragt, was mit den Managermillionen geschieht, z (...) rozm. Bahners, P. Cammann A., „Frankfurter Allgemeine Zeitung” 10 października.

Dylus A. (2016a), Polityka w perspektywie etycznej i religijnej, Wyd. Naukowe UKSW, Warszawa.

Dylus A. (2016b), Gospodarka w perspektywie etycznej i religijnej, Wyd. Naukowe UKSW, Warszawa.

Frühbauer J., Wirtschaftsdemokratie. Sichtung eines programmatischen Begriffs, Köln („Kirche und Gesellschaft" Nr. 400).

Gabriel I. (2012), Erosion der Demokratie? Eine Problemanzeige, Köln („Kirche und Gesellschaft” Nr. 394).

Habisch A., Hartmann M., Schmidt S., Wieland J. (Hrsg.) (2000), Globalisierung und Demokratie, LIT, Münster - Hamburg - London.

Hausner J. (2011), Demokracja i kryzys, „Zarządzanie Publiczne” nr 2-3.

Höffe O. (2004), Wirtschaftsbürger, Staatsbürger, Weltbürger - politische Ethik im Zeitalter der Globalisierung, C. H. Beck, München 2004; Held D., Soziale Demokratie im globalen Zeitalter, Suhrkamp Verlag, Frankfurt am Main 2007; cyt. za: [Gabriel 2012: 13].

Huntington S. (1993), Trzecia fala demokratyzacji, w: Szczupaczyński J. (opr.), Elity, demokracja, wybory, Agencja Scholar, Warszawa.

Isensee J. (2003), Die vielen Staaten in der einen Welt - eine Apologie, „Zeitschrift für Staats - und Europawissenschaften", H. 1.

Jaroszyńska M. (2008), Czynniki rozwoju i zagrożenia demokracji w dobie globalizacji, w: Domagała M., Iwanek J. (red.), Demokracja w dobie globalizacji, t. 2, Aspekty teoretyczne, Wyd. Uniwersytetu Śląskiego, Katowice.

Krasnodębski Z. (2003), Demokracja peryferii, Wyd. słowo / obraz terytoria, Gdańsk.

Kreikebaum H. (1999), Arbeit - Zukunft der Arbeitsgesellschaft, w: Korff W. (red.), Handbuch der Wirtschaftsethik, B. 4.1 (Konkrete Wirtschaftsethische Problemfelder. Arbeit - Schattenwirtschaft), Berlin University Press, Gütersloh.

Kuź M. (2015), Globaliści vs. Lokaliści, „Internetowy Miesięcznik Idei” nr 3 (57).

Novak M. (2001), Duch demokratycznego kapitalizmu, Wyd. W drodze, Poznań.

Nowotarski B. (2011), Demokracja i kryzys, „Zarządzanie Publiczne” nr 2-3.

Piekutowski J., Ubóstwo jako lęk, „Więź” nr 3.

Polak E. (2008), Globalizacja a zagrożenia dla demokracji, w: Domagała M., Iwanek J. (red.), Demokracja $w$ dobie globalizacji, t. 2, Aspekty teoretyczne, Wyd. Uniwersytetu Śląskiego, Katowice.

Rauscher A. (Hrsg.) (2007], Die fragile Demokratie - The Fragility od Democracy, Duncker \& Humblot, Berlin.

Rifkin J. (2001), Koniec pracy. Schyłek sity roboczej na świecie i początek ery postrynkowej, Wyd. Dolnośląskie, Wrocław.

Rymsza M. (2015), Nowa kwestia społeczna?, „Więź” nr 3. 
Saul J. R. (2006), Globalizacja dobiegła końca, „Europa” 28 października, nr 43 (dodatek do „Dziennika”); E. Thompson, Odkrycie świata na nowo, tamże.

Smolar A. (2011), Demokracja i kryzys, „Zarządzanie Publiczne” nr 2-3.

Standing G. (2015), Prekariat. Nowa niebezpieczna klasa, Wyd. Naukowe PWN, Warszawa 2014, s. 65-73; cyt. za: [Bednarski 2015].

Stawrowski Z. (2008), Niemoralna demokracja, Wyd. Ośrodek Myśli Politycznej, Wyższa Szkoła Europejska im. Józefa Tischnera, Kraków.

Surdykowska B. (2007), Związki zawodowe w świecie elastycznego zatrudnienia, „Dialog” nr 3.

Sztumski J. (2008), Szanse i zagrożenia demokracji w XXI w., w: Domagała M., Iwanek J. (red.), Demokracja w dobie globalizacji, t. 2, Aspekty teoretyczne, Wyd. Uniwersytetu Śląskiego, Katowice. Thielmann U. (2011), Das Ende der Demokratie, „Wirtschaftsdienst” Nr. 12.

Zięba M. (2016), Papieska ekonomia. Kościót - rynek - demokracja, Wyd. Znak, Kraków. Zwoliński A. (2010), Dylematy demokracji, Wyd. WAM, Kraków.

Jan Paweł II (2001), Globalizacja i etyka, „Więź” nr 10. 